\title{
COMPARATIVE LAW BEYOND POST-MODERNISM
}

\author{
Anne Peters* and Heiner Schwenke**
}

\section{INTRODUCTION}

THE legal version of post-modernism has not failed to challenge comparative law. It points out that, traditionally, comparatists bave participated in a project of objectivity, universalism and neutrality of law, of which the "new" approach to comparative law is altogether sceptical. ${ }^{1}$ In the era of globalisation, both the discipline and its critique have gained relevance. What the transition of post-socialist countries and the unification of Europe have effected regionally, globalisation now accomplishes on a global scale: it creates desires for harmonisation and, as a pre-requisite, legal comparison. However, not only the technical function of comparative law is needed, but also its critical potential. In the process of globalisation, different legal systems and different cultures are confronted with each other and must interact. This provokes new questions about the options and limits of comparative law and legal unification, regarding, for instance, the applicability of specific moral and legal standards to other cultures by comparatists and law-makers. These questions are all the more pressing as we begin to realise that governing globalisation, in particular economic globalisation, with the help of global law perhaps requires a concept of a global legal order which is based on a "global legal pluralism".

Challengers of the allegedly "ideological, methodologically flawed, and theoretically vacuous"3 traditional comparative law call their approach a

- Dr jur (Freiburg i.Br.), LL.M. (Harvard), Senior Lecturer and Researcher, Walther Schucking Institute for International Law, Christian Albrechts University at Kiel. The authors thank Larry Cata Backer, Ina Ebert and Mathias Reimann for helpful criticism on a previous version of this paper.

** Dr rer nat Dr phil (Freiburg i.Br.).

1. David Kennedy, "New Approaches to Comparative Law: Comparativism and International Governancen, (1997) Utah L.Rev. 545 at p.548.

2. Francis Snyder, "Governing Economic Globalisation: Global Legal Pluralism and European Law", (1999) 5 Eur. L.J. 334-374.

3. Gunter Frankenberg, "Stranger than Paradise: Identity \& Politics in Comparative Law", (1997) Utah L.Rev. 259 at p.265; see also Jonathan Hill, "Comparative Law, Law Reform, and Legal Theory", (1989) 9 Oxford J.Leg.Stud. 101 at p.113: "[C]omparative law in its 'applied version' ... is faced by very serious, if not insoluble theoretical problems". 
"critical" one," a "new approach", a "cultural immersion approach"6 or "engaged comparativism", ${ }^{7}$ while others have named those scholars, "discourse analysts", ${ }^{8}$ or-after a seminal conference at the University of Utah in October 1996-the "'Utah' group". The alternative new approaches have brought to comparative scholarship the tools of critical theory, feminism, literary theory, and postcolonial theory. Our article concentrates on specific features of those approaches and tools which we will gather under the label "post-modernist". This is of course a simplification which probably does not do justice to all facets and strands of new scholarship. Some of the authors we quote would perhaps not call themselves post-modernists. ${ }^{10}$ Also, we shall speak of the post-modernist argument, although there are many variations, which may be more nuanced than the aggressive version we are depicting here. However, we consider that simplification justified for the sake of clarity of the argument, which addresses only basic assumptions, and not their refined derivations.

Post-modernism is a highly ambiguous term, whose meaning depends on the discipline (literary theory, architecture, philosophy etc.) in which it is used, and on the prior notions of "modernism" and "modernity". Roughly speaking, post-modernist thought considers as basic the experience of plurality and difference. It points out that there are highly diverse forms of knowledge, systems of morality, personal plans of life and behavioural patterns. Post-modernist theory welcomes these heterogeneous positions and finds their discordance absolute. It protests against

4. Seminal Gunter Frankenberg, "Critical Comparisons: Re-thinking Comparative Law", (1985) 26 Harv.Int'l LJ. 411-455; sec also Nathaniel Berman, "Aftershocks: Exoticization, Normalization, and the Hermeneutic Compulsion" (1997) Uiah L.Rev. 281 at p.281.

5. See the Symposium "New Approaches to Comparative Law", held at the Utah Law School in October 1996, papers published in (1997) Utah L.Rev. 259 et seq.

6. Vivian Grosswald Curran, "Cultural Immersion, Difference and Categories in U.S. Comparative Law", (1998) 46 Am.J.Comp.L. 43, esp. at pp.50-54.

7. Berman supra n.4 at p.283: "there is no safe anchor, only engagement" (idem).

8. Annelise Riles, "Wigmore's Treasure Box: Comparative Law in the Era of Information", (1999) 40 Harv.Int'l L.R. 221 at pp.246-250. Riles paints a picture of currently three communities of comparative law ("traditional" comparative lawyers, "new approaches", and specialists in particular bodies of non-westem law), arguing that the three approaches are not so divergent as their proponents imagine because all scholars share the same passion for looking beyond and understanding differences. Idem at pp.221-283.

9. Nora Demleitner, "Challenge, Opportunity and Risk: An Era of Change in Comparative Law", (1998) 46 Am.J.Comp.L. 647 at p.648. Demleitner identifies three groups in the US-American academy: the establishment, the comparative law and economies group, and the critical "Utah" group.

10. Explicitly post-modernist however, Janet E. Ainsworth, "Categories and Culture: On the 'Rectification of Names' in Comparative Law", (1996) 82 Comell L.R. 19 at pp.24-25. 
the totalising monopolisation of certain types of rationality and against universalist concepts that raise false allegations of absoluteness."

Correspondingly, post-modernist criticism of traditional comparative law starts from the premise that reasoning, language and judgement are determined by inescapable and incommensurable epistemic, linguistic, cultural and moral frameworks. According to this theory, which we shall refer to as "framework-theory", ${ }^{12}$ legal comparison is trapped in cultural frameworks.

Comparative law is particularly vulnerable to the post-modernist critique. On a surface level, some favourite themes of post-modernists relate very obviously to our discipline. For instance, the post-modernists' focus on the Other is acute because comparative law, by definition, deals with the Other, being concerned with the differences between east and west, between common and civil law, between "us" and "them"; the "comparative enterprise is thus permeated by the other". 13 "

But the challenge goes deeper. The backbone to topoi such as the "Other", "difference", "categories" and "power", the framework-theory, actually calls into question the very essence of comparative legal scholarship. Until now, comparative study was all about exploring and transcending frameworks. Comparative law has been considered the specific tool to overcome parochialism, to become exposed, to enable distancing, to ultimately free observers from the narrow confines of their cultural disposition. To say that the comparatist is trapped in her framework casts fundamental doubts on this tool. The alleged incommensurability of frameworks means nothing else but total incomparability across history and culture. Because of irreconcilable differences, the comparatist cannot know, let alone compare and adjudicate different legal cultures. In short: incommensurability implies failure of comparison.

Part I of our article gives an overview of universalist strands in the comparative tradition (enlightenment, historicism, unificatory enthusiasm, and functionalism). In Part II, we review the post-modernist critique and respond to it. We refute the framework-theory by demonstrating that the relativism it builds on is not viable (Part II.1). We then discuss four other objections against traditional comparative law, which are-for the most part-closely related to the framework-theory. The first is the assertion that any comparative investigation is unavoidably biased (the bias-argument, Part II.2). Next we discuss the allegation that traditional comparative law obeys a secret political agenda of hegemony and

11. Wolfgang Welsch, Unsere postmoderne Moderne, 4th ed. (1993) at pp.4-7; see atso Elizabeth Deed Ermarth, "Postmodernism", in Edward Craig (Ed.) Routledge Encyclopedia of Philosophy 7 (1998), 587-590 with further references.

12. We borrow this term from Karl Popper. See Karl Popper, The Myth of the Framework: In defence of Science and Rationality (1994).

13. Grosswald Curran supra n.6 at p.45. 
domination (the hegemony-argument, Part ПI.3). We then turn to the critique of comparative categories and classifications (contempt of classifications, Part II.4). Then, we discuss the critical assertion that the traditional functionalist approach to comparative law belies deep differences between legal cultures, is inescapably subjective, only seemingly technical/apolitical and betrays a limited vision of the law (contempt of functionalism, Part II.5). To conclude, we suggest a methodology which takes into due consideration the post-modernist criticism and avoids its exaggerations and absurdities (Part III).

\section{The Challenged Tradition: Belief in Universal Law and} JUSTICE

\section{Enlightenment}

European comparative legal studies began with universalist aspirations in search of, so to speak, the lost unity of natural law. This was in the first half of the 19th century, when the great codifications in Bavaria, Prussia, France and Austria created diverse positive legal rules for specific territories, when the belief in one universal natural (divine) law was declining, and when even the ideal unity of the ius commune Europaeum had vanished. ${ }^{14}$ Comparison of the existing bodies of positive law had primarily idealist, rational, liberal, and enlightened motives. Comparatists tended to believe in the common nature of man as a rational being, they were mostly liberals (in the European sense) who favoured modern parliamentary legislation and studied foreign examples in search of material for codification, including projected constitutions. ${ }^{15}$

\section{Historicism}

The second strand of universalism in comparative studies was historicism, which in the 19th century became the leading paradigm of almost all sciences. $^{16}$ Legal comparison (including historical comparison) was undertaken in order to construe a necessary progress of legal evolution. A good example is Eduard Gans' "Law of Succession in UniversalHistorical Evolution: A Treatise of Universal History". Under this programmatic heading, Gans treated Roman, Indian, Chinese, Mosaic, Muslim and Attic law of heritage, explicitly relying on Hegel's philosophy

14. Michael Stolleis, Nationalitat und Internationalitat: Rechtsvergleichung im offentlichen Recht des 19. Jahrhunderts (1998) at pp.7-8.

15. Idem at p.10.

16. The historicist drive of 19th century comparative scholarship was so pervasive that even in 1903 Frederick Pollock wrote: "It makes no great difference whether we speak of historical jurisprudence or of comparative jurisprudence, or, as the Germans seem inclined to do, of the general history of law." Frederick Pollock, "The History of Comparative Jurisprudence", (1903) 5 Journal Soc. Comp.Leg. 2nd ser. 74 at p.76. 
of history as a theoretical foundation. ${ }^{17}$ Another leading comparatist of that period, Josef Kohler, wrote in his "Introduction to Comparative Law": "[W]e see how the immanent aspiration to development in the organism called mankind unconsciously sprouts and bears fruit, we see how above all individual reason the higher reasonableness pervades mankind and directs history". ${ }^{18}$ Kohler's world-view has been rightly characterised as "historical optimism"; 19 and such optimism was shared by others, such as John Stuart Mill, who observed in 1848: "It is hardly possible to overstate the value ... of placing human beings in contact with persons dissimilar from themselves, and with modes of thought and action unlike those with which they are familiar.... Such communication has always been ... one of the primary sources of progress."20

The idea of organic evolution of the law led jurists to look for basic structures of the law, for a "morphology" of the law, of the State, etc."1 Lawyers searched and constructed such evolutionary patterns in order to find the "right law".22 Thus in the first volume (1878) of the newly founded journal "Zeitschrift fur vergleichende Rechtswissenschaft", one of the editors formulated the objectives of comparative legal studies entirely within the evolutionary paradigm: "[C]omparative law wants to teach how peoples of common heritage elaborate the inherited legal notions for themselves, how one people receives institutions from another one and modifies them according to its own views, and finally how legal systems of different nations evolve even without any factual interconnection according to the common laws of evolution. It searches, in a nut-shell, within the systems of law, the idea of law."23

17. Eduard Gans, Das Erbrecht in weltgeschichllicher Entwickclung: Eine Abhandlung der Universalrechisgeschichte (1824) at p.XXXIX. See within the same-Hegelianparadigm Joseph Unger, Die Ehe in ihrer welthistorischen Entwicklung: Ein Beitrag zur Philosophie der Geschichte (1850). Translation, here and in following references to German sources by Anne Peters.

18. Joseph Kohler, Einleitung in die vergleichende Rechtswissenschaft (1885).

19. Wolfgang Gast, "Historischer Optimismus: Die juristische Weltsicht Josef Kohlers", Zeitschriff fur vergleichende Rechtswissenschafi 85 (1985) 1.

20. John Stuart Mill, Principles of Political Economy, (1848) Book III, Chap. XVII, 85.

21. The famous German political economist Wilhelm Roscher published in 1892 a book called "Politik: Geschichtliche Naturlehre der Monarchie, Aristokratie und Demokratie". He considered three typical forms of government as three stages of evolution of political life, which until today and for all times shape government. The primary form of government is the monarchy, followed by the aristocracy, then democracy, declining as a plutocracy, finally the circle is completed by a new monarchy (caesarism) (pp.12-13). He deemed these forms to be universal and "rooted in certain inexterminable human conditions" (p.8).

22. Erich Rothacker, "Die vergleichende Methode in den Geisteswissenschaften", (1957) 60 Zeitschrifi fiur vergleichende Rechtswissenschafi 13 at p.17.

23. Franz Bemhoft, "Ueber Zweck und Mittel der vergleichenden Rechtswissenschaft", (1878) 1 Zeirschrifi filr vergleichende Rechiswissenschafi 1 at pp.36-37. 
A related stream of comparative scholarship was the so-called comparative anthropology (Rechtsethnologie) ${ }^{24}$ One of its founders, Albert Hermann Post, assumed that "there are general forms of organisation lying in human nature as such, which are not linked to specific peoples". He sought to explain the causes of these generalities empirically, through comparison. "[F]rom the forms of the ethical and legal conscience of mankind manifested in the customs of all peoples of the world, I seek to find out what is good and just.... I take the legal customs of all peoples of the earth as the manifestations of the living legal conscience of mankind as a starting-point of my legal research and then ask, on this basis, what the law is." ${ }^{26}$ So, despite their lost faith in natural law, scholars still believed in a universal truth, hidden under historical and national variations, which could be uncovered through legal comparison. As the important German philosopher Wilhelm Dilthey put it: "As historicism rejected the deduction of general truths in the humanities by means of abstract constructions, the comparative method became the only strategy to reach general truths."27

In a way antagonistic to historicist universalism was the old theme of the dependency of law on the local conditions, which had already been brought to the fore by Montesquieu. ${ }^{28} \mathrm{~A}$ hundred years later, the influential German historical school of law considered law to be the product of the Volksgeist, and thus particular to every nation. ${ }^{29}$ Especially the Romanist branch of this school, with its fixation on Roman law and on

24. Critics observe that the background of this type of research was colonialism and imperialism, which needed comparative anthropology, not in order to leam from foreign nations, but rather in order to justify the expansion of European interests across the globe.

25. "[C]omparative-ethnological research seeks to acquire knowledge of the causes of the facts of the life of peoples by assembling identical or similar phenomena, wherever they appear on earth and by drawing conclusions about identical or similar causes." Albert Hermann Post, Bausteine fur eine allgemeine Rechtswissenschaft auf vergleichend-ethnologischer Basis (1880), Vorrede, citations at pp.12-13. Other important works of this school are idem, Einleitung in das Studium der ethnologischen Jurisprudenz (1886); Henry Maine, Ancient Law, 3d ed. (1866).

26. Albert Hermann Post, Die Grundlagen des Rechts und die Grundzlige seiner Entwicklungsgeschichte: Leitgedanken fur den Aufbau einer allgemeinen Rechtswissenschaft auf sociologischer Basis (1884) at p.XI.

27. Wilhelm Dilthey, "Der Aufbau der geschichtichen Welt in den Geisteswissenschaften", in idem, Gesammelie Schrifien, Vol. VII (4 ed. 1965) (orig. 1910) 77 at p.99.

28. Charles de Secondat Montesqieu, De l'Esprit des lois (1748), book I, chap. 3.

29. See Friedrich Carl von Savigny, Vom Beruf unserer Zeit fir Gesetzgebung und Rechiswissenschaft (1840), p.8: "Where we first find documented history, the civil law has already a determinate character, peculiar to the people, just as have their language, manners, constitution." Or elsewhere: "If we ask further for the subject in which and for which positive law has its existence, we find this is the people. Positive law lives in the common consciousness of the people, and we therefore have to call it people's law (Volksrecht)... [I]t is the spirit of the people (Volksgeist), living and working in all the individuals together, which creates the positive law ..." (idem, System des heutigen romischen Rechis, Vol. I (1840) at p.14). 
legal notions (Begriffsjurisprudenz), was ambivalent towards the comparative study of living legal systems. ${ }^{30}$

Moreover, the rise of nationalism and legal positivism favoured concentration of scholars on their own nations and on the printed legal texts. This change of climate had a stunting effect on comparative legal studies. ${ }^{31}$ In 1852, Rudolf von Ihering deplored the degradation of legal science to "national jurisprudence", which he considered a "humiliating and unworthy form of science". He called for comparative legal studies, which would restore the discipline's "character of universality". ${ }^{32}$

\section{Intra-and Transnational Unification}

The universalist character of legal science reclaimed by Ihering was soon brought about by industrialisation and the internationalisation of the economy, the third promoter of universalism in comparative law. Beginning already in the $1840 \mathrm{~s}$, technical and economic developments had spurred extraordinary legislative activity in order to modernise the State and regulate new fields. The drafting of the new codes was based on extensive legislative comparison, undertaken or mandated by the legislators themselves. These practical endeavours, together with the increase of transnational economic activities, led to a new heyday of legal comparison as a scholarly discipline in Europe, mostly related to technical and commercial law. ${ }^{33}$ The predominant motives of legal comparison appeared to be, first, stock-taking for national legislation and intra-

30. In retrospect, one of the pioneers of comparative law, Felix Meyer, said that in 1894, mainstream scholarship "bemoaned [the comparative discipline] as dilettantism and as Utopian project, looked pitifully down on it from the heights of Roman law as the beatific ratio scripta." His address is reproduced in Karl von Lewinski, "Die Feier des zwanzigjahrigen Bestehens der Internationalen Vereinigung für vergleichende Rechtswissenschaft und Volkswirtschaftslehre", 9 (1914) Blditer fur vergleichende Rechiswissenschaft und Volkswirtschafislehre Suppl. to issue 9,2-3. See on the rclationship of the historical school to comparative law Stolleis supra n. 14 at p.24; Konrad Zweigert \& Hein Kötz, Introduction to Comparative Law-The Framework (1969), (Tony Weir, trans., 3d ed. 1998) at 84 I; Elmar Wadle, Einhundert Jahre Rechisvergleichende Gesellschafien in Deutschland (1994) at p.17.

31. Walther Hug, "The History of Comparative Law", 45 (1931/1932) Harv. Intl L.R. 1027 at p.1069-7; Zweigert \& Kotz supra n.30 at 84 III 3; Stolleis supra n.14 at pp.12, 24.

32. Rudolph von Ihering, Der Geist des Romischen Rechis auf den verschiedenen Siufen seiner Entwicklung, Vol. I, 9th ed. (1955) (1st ed. 1852) at p.15. Ihering's complaint was justified to the extent that German lawyers in particular were preoccupied with their own country, because German unification was, to say the least, one of the most pressing subjects of the time. But this did not quite do justice to the discipline as a whole.

33. See for the comparatist mood Felix Meyer, speaking in 1914: "... today, when the internationalisation of the law has made enormous progress, when no Act is passed without legal comparison and the global economic tendency is manifest in ever newly emerging societies and institutes" (Lewinski supra n.30 at p.3). Seminal works were Josef Kohler, Deutsches Patentrechi, Systematisch bearbeitet unter vergleichender Berticksichtigung des französischen Patentrechis (1878); idem (ed.), Das Rechi des Markenschutzes mil Berlicksichrigung ausländischer Gesetzgebungen und mit besonderer Rücksicht auf die englische anglo-amerikanische, franzbsische, belgische und italienische Jurisprudenz (1884/85). 
national harmonisation, and later, when codification was basically completed in most European countries, international harmonisation. At the first international conference on comparative law, the famous Paris Congress of 1900, the French comparatist Raymond Saleilles described the object of comparative law as the discovery of concepts and principles common to all "civilised" systems of law, that is to say universal concepts and principles which constitute a relatively ideal law: "[L]e droit comparé n'est que l'idéal relatif résultant de la comparaison des legislations". ${ }^{34}$ The same seminal Congress established the principle that the ultimate goal of any legal comparison should be legal unification. ${ }^{35}$ And at the 20th anniversary of the German "International Association for Comparative Law and National Economics", celebrated at the eve of World War I in Berlin, its founder, Felix Meyer, repeated that the association, remaining "true to the principle 'Through legal comparison towards legal unification', seeks to develop and harmonise the law". ${ }^{36}$ Unification as the necessary consequence of legal comparison and as its ultimate accomplishment clearly reflected the broad universalising hopes of the early comparatists. ${ }^{37}$

In addition, the plans for unification, mostly in the field of private law, mirrored the general legal methods of the time in their favourable attitude towards grand projects of systematisation. One hidden promoter of that trend was probably the German Begriffsjurisprudenz ${ }^{38}$ with an approach which placed high emphasis on definitions and classifications to create a systematic, stringent body of positive law. Although Begriffsjurisprudenz and legal positivism generally tended to disdain comparative legal studies, ${ }^{39}$ comparatists themselves were arguably influenced by

34. Raymond Saleilles, "Conception et objet de la science juridique du droit compare" in Proces verbaux et documents du Congres international de droit compare 1900. (1905-1907) Vol. I, 167 at p.173. He continues: "Le droit compare cherche à definir le type idéal tout relatif qui se dégage de la comparaison des législations, de leur fonctionnement et de leurs resultats".

35. See Pan. J. Zepos, "Die Bewegung zur Rechtsvereinheitlichung und das Schicksal der geltenden Zivilgesetzbulcher", (1966) 19 Revue hellenique de droit international 14 at pp.17-18.

36. Lewinski supra n. 30 at p.3. Karl von Lewinski concluded his report on the celebration with the words: "May we succeed jointly to contribute continuously to our part of the proud edifice of science that links nations, in which in the future all nations shall reside peacefully next to each other." (idem, at p.9).

37. "The spirit of universalism, which was perceptible already before, but especially in the last century, is the foundation of all ideas of a unification of the lawn (Zepos supra $n .35$ at p.16).

38. Georg Friedrich Puchta, Cursus der Institutionen, Vol. I (1841), esp. pp.95-108; Bernhard Windscheid, Lehrbuch des Pandektenrechis (3 volumes), 7th ed. (1891) (1st ed. 1862), esp. Vol. I, \$24 (pp.59-60); Rudolph von Ihering supra n.32, with the notorious phrase at p.40: "Notions are productive, they mate and generate new ones".

39. See Emst Rudolf Bierling, Juristische Prinzipienlehre, Vol. I (1894, repr. 1961) at p.33 (expecting "little or no use" of comparative law). 
this approach, and became eager to classify and categorise, concentrating on formal rules, institutions, and procedures, and ignoring the rules' full social and economic context. ${ }^{40}$ On the other hand, the new wave of comparative law was in line with jurisprudential trends that were emerging as a counter-reaction to legal positivism in all forms, such as Zweckjurisprudenz," Interessenjurisprudenz, ${ }^{4}$ precursors of legal realism, ${ }^{43}$ and sociological jurisprudence. ${ }^{4}$ These new approaches were, inter alia, seed-beds of functionalism in comparative law.

\section{Functionalism}

The functional approach may be considered as the fourth strand of (implicit) universalism in comparative scholarship. It was suggested in the $1920 \mathrm{~s}$ in order to overcome previous formalism. ${ }^{45}$ The novelty of the functional approach was that comparative analysis now set off from a concrete social problem. In other words, the starting point is not considered the law, or the structure of legal institutions, but the facts. ${ }^{46}$ The founder of functionalism, Ernst Rabel, described as a common denominator for every comparison "the social purpose of the rules and the service of the concepts to this purpose. This is now aptly called the functional approach." ${ }^{47}$ Functionalists consciously broke with the goals and methods of the nineteenth century scholars. They disqualified traditional comparative law as a mere "synoptic description of legal rules and institutions". ${ }^{48}$ They eschewed rigid adherence to any taxonomy of legal systems and arid classifications, although in real research, the old classification schemes still played a role. The functionalist program, as formulated by Max Rheinstein, is that comparative law must "go beyond the taxonomic or analytical description or technical application of one or more systems of positive law.... [E]very rule and institution has to justify its existence under two inquiries: First, What function does it serve in

40. Mary Ann Glendon, Abortion and Divorce in Western Laws (1987) at pp.3-4.

41. Rudolph von thering, Der Zweck im Recht, 2 Vols. (1877).

42. Philipp Heck, "Gesetzesauslegung und Interessenjurisprudenz", (1914) 112 Archiv fur die civilisrische Praxis 1-318.

43. Oliver Wendell Holmes, Jr., The Common Law (1881) at p.1: "The life of the law has not been logic: it has been experience." Idem, "The Path of the Low", (1897) 10 Harv. Intl L.R. 457-478.

44. Roscoe Pound, "The Scope and Purpose of Sociological Jurisprudence", (1911) 24 Harv. Intl L.R. 591-619; (1911/12), 25 Harv. Intl L.R. 140-168, 489-516.

45. Ernst Rabel, Aufgabe und Norwendigkeit der Rechtsvergleichung (1925) at p.4.

46. Sec, e.g., Max Rheinstein, Einfahrung in die Rechtsvergleichung. 2nd ed. (1987) at p.33.

47. Ernst Rabel, "Some Major Problems of Applied Comparative Law, especially in the Conflict of Law (summary)", in Association of American Law Schools (ed.) Summarized Proceedings of the Institute in the Teaching of International and Comparative Law (1948) at p.111.

48. Max Rheinstein, "Teaching Comparative Law", (1938) 5 U.Chi.L.Rev. 615 at p.618. 
present society? Second: Does it serve this function well or would another rule serve better?" $\mathrm{W}$. J. Kamba put the guiding question like this: "[W]hat legal norms, concepts or institutions in one system perform the equivalent functions performed by certain legal norms, concepts or institutions of another system?" 50 The functional approach spread from Europe to the United States (where the leading post World War II comparatists were émigrés from Europe) and has dominated comparative legal studies until today. ${ }^{51}$

The more recent comparative law and economics approach ${ }^{52}$ may be regarded as a narrowed and specified version of functionalism, looking not broadly at social functions, but exclusively at one particular function, namely the rule's or institution's efficiency, in purely economic terms.

Today, quite a few comparatists are openly universalists, either through their description of the laws or by suggesting how a uniform legal order ought to be. ${ }^{53}$ The best-known descriptive version is probably Rudolf Schlesinger's common-core-theory, according to which "-even in the absence of organised unification efforts-there exists a common core of legal concepts and precepts shared by some, or even by a multitude, of the world's legal system."

Besides, there is a concealed universalism inherent to the functionalist approach. It applies objectivity and universality of the law, because it rests on the assumption that "the legal system of every society faces essentially the same problems, and solves these problems by quite

49. Idem at pp.617-618.

50. W. J. Kamba, "Comparative Law: A Theoretical Framework", (1974) 23 I.C.L.Q. 485 at p.517.

51. See Zweigert \& Koiz supra n.30 at pp.32-47.

52. Ugo Mattei, Comparative Law and Economics (1997).

53. See only Rene David \& John E. C. Brierley, Major Legal Systems in the World Today. 3d ed. (1985) at pp.4-6. For Myres McDougal, the goal of legal unification is to expand a democratic world order: "Most broadly conceived, that central, overriding purpose [of comparative law] is ... the clarification for all our communities-from local through national and regional to global-of the perspectives, the conditions, and the alternatives that are today necessary for securing, maintaining, and enhancing basis democratic values in a peaceful world." (Myres S. McDougal, "The Comparative Study of Law for Policy Purposes: Value Clarification as an Instrument of Democratic World Order", in William Elliot Butles (Ed.) Intemational Law in Comparative Perspective (1980) 191 at p.196). Kaiser speaks of framing a "general theory of democratic-liberal constitutional law". Joseph H. Kaiser, "Vergleichung im offentlichen Recht", (1964) 24 Zeitschrift für auslandisches offentliches Recht und Volkerrecht 391 at p.399. Zweigert \& Kotz supra n.30 at $\$ 4$ l, admit that comparative legal studies with the objective of finding better solutions have an affinity to natural law speculations.

54. "At least in terms of actual results-as distinguished from the semantics used in reaching and stating such results- the areas of agreement among legal systems are larger than those of disagreement." "[T] he existence and vast extent of this common core of legal systems cannot be doubted." Rudolf B. Schlesinger/Hans W. Baade/Mirjan R. Damaska/ Peter E. Herzog, Comparative Law: Cases-Text-Materials. Sth ed. (1988) at pp.34-35, 39. 
different means though very often with similar results." theory is that law is an answer to the needs of society and a body of "specialized instruments of social control". $\$ 6$

As a matter of fact, regional integration and globalisation are nowadays levelling economic, political and moral standards, as well as lifestyles in different countries. On the before-mentioned premise that legal rules primarily react to social needs, they must naturally converge as well. National characteristics of legal rules will gradually disappear with the emergence of a global society, the theory runs. ${ }^{57}$ So the strict sociofunctional view of the law almost inevitably leads to a theory of the gradual convergence of legal systems. ${ }^{58}$ The question is, however, whether or not natural convergence is merely a euphemism for NorthAmerican, and to a lesser extent, European "legal imperialism". 59

55. Zweigert \& Kotz supra n.30 at p.34; but see much more cautiously Hein Kotz, "Abschied von der Rechtskreislehre?", (1998) 6 Zeisschrifi filr europdisches Privatrecht 493-505 at pp.504-505 (limited value of the functional approach). Critically Frankenberg (1985) supra n.4 at p.436: "The functional approach runs the risk of simplifying complex reality by assuming that similarity of problems produces similarity of results."

56. Roscoe Pound, "Comparative Law in Space and Time", (1955) 4 Am.J.Comp.L. 70 at p.72; similarly Rheinstein (1938) supra n.44 at p.619.

57. See, e.g., Michael King, "Comparing Legal Cultures in the Quest for Law's Identity", in David Nelken (Ed.), Comparing Legal Cultures (1997) 119 at p.132.

58. Vincenzo Ferrari, "Socio-legal Concepts and Their Comparison", in Else Oeyen (Ed.) Comparative Methodology (1990) 63 at p.69; Basil Markesinis (Ed.), The Gradual Convergence: Foreign Ideas, Foreign Influences, and English Law on the Eve of the 2Ist Century (1994); Peter De Cruz, Comparative Law in a Changing World (1995) at pp. 477-489; Reinhard Zimmermann, "Common law' und 'civil law', Amerika und Europazu diesem Band," in Reinhard Zimmermann (Ed.), Amerikanische Rechiskultur und europdisches Privatrecht (1995) 1 at p.2; Kotz supra n.55 at pp.497-504. The critical perspective on this issue is represented by Pierre Legrand, "European Systems are not Converging", (1996) 45 I.C.L.Q. 52-81 (arguing that common and civil law systems are irreducibly different).

59. Arthur T. von Mehren, "An Academic Tradition for Comparative Law?", (1971) 19 Am.J.Comp.L. 624 at p.625; see also Rolf Knieper, "Rechtsimperialismus?", (1996) 29 Zeitschrifi far Rechtspolitik 64-67 (recommending inter-regional harmonisation and reliance on local traditions in post-communist societies); critical towards the "ideology of convergence" also Hill supra n.3 at p.110. 


\section{Post-modernist Objections against Comparative Law and THEIR FLAWS}

\section{Legal Comparison: Trapped in Irreconcilable Frameworks?}

a) Cultural Framework-Relativism

Post-modernists assert that traditional comparisons are only a pretence of empiricism, only a projection of the scholar's own imagination. ${ }^{60}$ This is so because there is no external stand-point from which to describe, compare, and assess legal solutions. ${ }^{61}$ Comparatists "need to accept that the others have different truths". ${ }^{62}$

The base-line and key assumption of this criticism is what we have called the framework-theory. The framework-theory holds that there is no common denominator that guarantees the possibility of neutral and objective meaning and value. No autonomous world of meaning and values exists, but all systems are self-contained, self-referential and relative. Therefore, legal thought, language, and judgement are determined by inescapable epistemic, linguistic, cultural and moral frameworks. ${ }^{63}$ Frameworks are institutionalised so that comparatists are dominated "by a grid of concepts, research techniques, professional ethics, and politics, by which the prevailing culture imposes on the individual scholar its canons of how legal scholarship is to be conducted." $" 64$

Because of the belief in insurmountable frameworks, the post-modern approach naturally focuses on the "problems of perspective as a central and determinative element in the discourse of comparative law".s

60. David Kennedy thinks of international law "as establishing itself through an ongoing process of imagination, creating doctrines and institutions as efforts to transcend and bridge what it imagines as differences in a world of cultures it seeks to hold at arm's length ... comparative law shares this imaginative construction from the other side, seeing itself ... as an intellectual project of understanding between cultures whose similarities and differences are foregrounded." Kennedy supra n.l at p.554.

61. "[T] he comparativist must relinquish the comfortable position of the outside observer: if the Other is internally split and decisively inflected by the West (and vice versa), then there is no wholly neutral position in which the comparativist can stand." Berman supra n.4 at p.282 (emphasis added).

62. Grosswald Curran supra n.6 at p.91; see in that sense also Pierre Legrand, "Sur l'analyse differentielle des juriscultures", (1999) 51 Revue internationale de droit compart 1053 at p.1062.

63. One of the seminal contributions was François Lyotard's La condition postmoderne: Rapport sur le savoir (1979). Lyotard identifies as characteristics of the post-modern era the obsoleteness of meta-narratives, which were in modern times used to legitimise institutions, social and political practices, ethics and modes of thought. From the obsoleteness of meta-narratives results the irresolvable incommensurability of language games, which make consensual notions of truth and justice impossible.

64. Frankenberg (1997) supra n.3 at p.270. Note that by saying that the scholar needs "a deconstructive move - ... breaking down the conceptual repression", the critic himself seems-in somewhat contradictory terms - to imply that this is possible.

65. Frankenberg (1985) supra n.4 at p.411 (emphasis added). 
Correspondingly, the new "immersion approach implies a multiplicity of standards, each true in its own legal culture."66

Most other new themes relate to the framework-theory: because there is no escape from one's framework, all that can be done is to deconstruct the ambiguities and indeterminacies within the dominant discourse, including the internal contradictions and assumptions about the character of foreign law. ${ }^{67}$ Similarly, the post-modern aversion to naive interpretation of foreign texts has to do with that key-assumption. Interpretation should first of all, in this view, seek to detect hidden purposes, meanings, themes in familiar and foreign texts: in short, uncover the respective framework. Because of the importance ascribed to frameworks, the focus of interest shifts from the laws to be compared to the history, epistemology and politics of comparative research itself, ${ }^{68}$ always on the watch for tacit assumptions: "We must change the project of comparative law from a naive epistemological project ("how best can we truly understand the Other'?) to a critical and interventionist project ('what critical resources exist both within one's "own" frame of reference and within the "Other's" that can be deployed for emancipatory purposes?')". ${ }^{69}$

Under the premise that diverging, irreconcilable, cultural frameworks make legal transplants futile, one considers that comparisons are less a practical tool of law reform or legal harmonisation, but either art for art's sake or overt and self-consciously "political projects of critique"70-both seemingly antagonist types of post-modernist comparative endeavours sharing an atechnical, explicitly subjective drive.

The foregoing paragraphs have, hopefully, underscored and illustrated that the premise of the irreconcilable framework is the very bedrock of the post-modernist approach to comparative law: "The full meaning of laws can be understood only by viewing laws through the prism of the intellectual framework in which they exist."' Note that the gist lies not in the hardly deniable proposition that throughout history and geography we have a plurality of epistemic, normative, and cultural frameworks. The problem lies in the assertion that these frameworks are incommensurable, and this assertion will be discussed here.

66. Grosswald Curran supra n.6 at p.64.

67. Cf. Riles supra $\mathrm{n} .8$ at p. 248 .

68. See as an example Jorge L. Esquirol, "The Fictions of Latin American Law (Part I)," (1997) Utah L.Rev. 425, analysing Rene David's comparative work on Latin American Law.

69. Berman supra n.4 at p.281. See also Gunter Frankenberg (1997) supra n.3.

70. Kennedy supra n.1 at p.633. See also, idem at p.632, and generally pp.606-637 on the "Politics" and Governance Projects of Comparative Law.

71. Catherine Rogers, "Gulliver's Troubled Travels, or The Conundrum of Comparative Law", (1998) 67 George Washington L.Rev. 149 at pp.161-162. See also Grosswald Curran supra n.6 at p.67 on "underlying, sometimes irreconcilable, differences among legal systems"; also Legrand (1999) supra n.62 at p.1056. 


\section{b) Refutation}

The post-modernist claim that comparative studies are basically a projection, an outgrowth of our specific cultural framework, a futile attempt to compare the incomparable, implies a type of relativism which we shall call framework-relativism. We are aware that quite a few of the critics explicitly try not to fall into relativism, while still holding on to the dogma of the inescapable framework. ${ }^{n}$ However, the assertion that there is some "in-between space" represents an attempt to wash the fur without wetting it. We will therefore refute cultural framework-relativism and thereby hit the hard core of the post-modernist critique.

\section{Relativism Defined}

Relativism is the position that neither universal knowledge exists (epistemic relativism), nor universally valid norms (moral relativism), because insights and values always depend on the standpoint of the epistemic or moral subject. Epistemic relativism is concerned with the relativity of the existence of facts, while moral relativism relates to the relativity of the validity of values. ${ }^{73}$ Framework-relativism may refer both to epistemics and to morals and is the assertion that all thinking and/or judging takes place within insurmountable frameworks. ${ }^{74}$ The framework-relativism underlying the post-modern critique of traditional

72. See, e.g., Brenda Crossman, "Turning the Gaze Back on Itself: Comparative Law, Feminist Legal Studies, and the Postcolonial Project", (1997) Utah L.Rev. 525 at pp.526-527 and 537; Hartmut Rosa, "Lebensformen vergleichen und verstehen. Eine Theorie der dimensionalen Kommensurabilităt von Kontexten und Kulturen", (1999) 1 Handlung. Kultur, Interpretation: Zeitschrift fur Sozial- und Kulturwissenschafien 10 at p.24. With regard to international law, David Kennedy likewise asserts that new approaches are on their way to overcoming the "routine conflict between defenses of its overt accultural posture and assertions of cultural relativism", (Kennedy supra n.1 at p.569).

73. Our distinction of two basic types of relativism presupposes a fact-value-distinction. This runs counter to the post-modernist tendency, which denies that facts and morals are two separable spheres. Not surprisingly, the post-modernist conflation of facts and morals goes very well with the negation of the existence of truth: Theories do not aim at the truth, but instead they seek to veil practical or moral attitudes, especially aspirations to power. However, facts and norms are two distinct categories. Norms guide and improve the conduct of humans, theories explain and predict, inter alia, the conduct of humans (Gerhard Schurz, The Is. Ought Problem. An Investigation in Philosophical Logic (1997) at p.279). Normative expressions can never replace ontological expressions salva veritate, and norms are not derivable from facts, as Gerhard Schurz has recently explained in detail. There is no logical bridge between norms and facts (idem, especially at pp.278-285). We can therefore uphold the distinction between epistemic and moral relativism. This distinction does not preclude a psychological interrelatedness in practice. Assumptions about what is "good" and "evil" may psychologically influence what we hold to be true. For instance, we may be reluctant to recognise our own personal properties that we find morally undesirable.

74. See in detail on framework-relativism infra pp.822-824. 
comparative law is a group-based relativism, ${ }^{75}$ more specifically a cultural relativism, because the boundaries of the frameworks run along the boundaries of cultures.

\section{Objections against Cultural Relativism}

We will first look at cultural relativism in general. It can be attacked through a number of arguments, some of which are simple and forceful. We will make two here.

In a cross-cultural discourse one cannot consistently hold that cultural relativism is true not only for their own culture but also for other cultures: Asserting that two persons from two cultures can never have commensurable theories and trying to convince a person from another culture of the truth of cultural relativism at the same time is self-contradictory.

Another simple argument against cultural relativism is that cultures are not hermetic, closed, immutable entities. ${ }^{76}$ Cultures, in contrast to individuals, do not have readily determinable boundaries. And if boundaries between cultures are blurry, the boundaries of the epistemic and moral furniture of different cultures are blurry as well. Radical difference or incommensurability cannot exist here. Examples of blurriness and overlaps are easy to point out. Individuals can participate in several cultures, for instance, simply by spending half of the year in Norway and the other half in Spain. Also, there are those born into two frameworks. Mass media and travelling spread elements of specific cultures around the globe. It is well-known that the U.S.-American culture has been and is continuing to infiltrate many other cultures of the world. Also, differences within one culture may be greater than differences between cultures. Within a formation which is perceived as one culture, there may be a dissent even about central elements of this culture. For instance, some may consider the culture of the New World as necessarily hybrid. Within "one" culture, we may find sub-cultures (for example, a youth-culture). Some of these sub-cultures, such as the various sub-cultures of scientists around the globe, may have more in common with each other than with other members of their national culture. For instance, the attitudes, interests, and style of living of a German entomologist probably resembles more that of a Canadian entomologist than those of a German blue-collar worker.

75. Historically, philosophers mostly thought of relativism (epistemic or moral) as individually-based, as a relativism of the "I" (beginning in Western philosophy with the sophists). Today, it is virtually always a group-based relativism that is discussed. In the "l"-relativism, all insights and values are valid only for one person, in group-based relativism they are shared by the members of a group, e.g., a culture.

76. See Elmar Holenstein, Menschliches Selbstverständnis, Ichbewuptsein, Intersubjektive Verannworiung, Interkuliurelle Verstandigung (1985) at pp.104-180. 
The haziness of boundaries becomes most apparent as soon as we look at a culture through time. Is the culture of Germany still the same as it was 500 years ago? At which point do we have to recognise a different culture? In any case, an average contemporary German would most likely have less problems to get around, make his living, participate in leisure-time activities in the Great Britain or Sweden of our days than in Germany of 500 years ago. ${ }^{7}$

With regard to the relevance of cultural relativism for comparative law, one should note that a single legal system can comprise various cultures (think of the EU legal system) or one culture different legal systems (think of Germany in the middle of the 19th century).

\section{Objections against Cultural Framework-Relativism}

Having made these two arguments against cultural relativism in general, we shall now turn to cultural relativism in the form of frameworkrelativism. Karl Popper defines framework-relativism as "the doctrine that truth is relative to our intellectual background, which is supposed to determine somehow the framework within which we are able to think: that truth may change from one framework to another" ${ }^{78}$ Popper maintains that behind this practice of operating in frameworks, which he calls "myth of the framework", lurks the occidental dogmatic fundamentalism, the old axiomatic-deductive mode of reasoning, in which principles or axioms cannot be questioned and determine all further

77. See also Thierry Lenain, “Understanding the Past: History as an Intercultural Process", in Notker Schneider, Ram A. Mall \& Dieter Lohmar (Eds.), Einheit und Vielfalt: Das Verstehen der Kuluren (1998), 145-154, esp. at p.145: "But this concept [of interculturality] can and should be extended to the question of historicity, for when we face past periods of our own culture on a critical mode, we are dealing with cultural systems which prove as different from ours as any present-day 'exotic' culture would be."

78. Popper 1994 supra n.12 at p.33. In fact, Popper identifies relativism in general with framework-relativism. This is not correct, because relativism can also have a non-cognitive foundation, i.e. must not be due to a special mode of thinking (e.g. axiomatic thinking), but may for instance be due to psychological states. 
thought. ${ }^{79}$ This axiomatic-deductive structure of the frameworks is the reason why they are insurmountable: if principles can never be questioned on the basis of new experience, but-on the contrary-any experience must be interpreted in the light of the principles (the theory-loadedness of observation), then we are never capable of achieving new knowledge or accept new values which contradict our own principles. ${ }^{80}$

Of course, such an axiomatic deductivism is conceivable, we say, but the question is whether it is an appropriate model for real human thinking. Our argument against it, and thereby against frameworkrelativism, is that it contradicts the indispensable and not really contestable everyday-life view that one can-as every child does-experience something fundamentally and surprisingly new. The concept of the closed framework represents a kind of solipsism or subjective idealism, in which reality does not play any role. Such a theory which does not allow the acquisition of genuinely new knowledge is not acceptable, even if we still have no generally acknowledged philosophical answer to the question of how knowledge is obtained. Such an answer would surely have to make the point that people do not only reason from the top down (deductively), but also from the bottom up (inductively) and are capable of modifying their principles due to new experiences. And we think that, in particular,

79. Jdem at pp.59-60: "The myth of the framework is clearly the same as the doctrine that one cannot rationally discuss anything that is fundamental, or that a rational discussion of principles is impossible. This doctrine is, logically, an outcome of the mistaken view that all rational discussion must start from some principles or, as they are often called, axioms, which in their turn must be accepted dogmatically if we wish to avoid an infinite regress-a regress due to the alleged fact that when rationally discussing the validity of our principles or axioms we must again appeal to principles or axioms. Usually those who have seen this situation either insist dogmatically upon the truth of a framework of principles or axioms, or they become relativists; they say that there are different frameworks and that there is no rational discussion between them, and thus no rational choice. But all this is mistaken. For behind it there is the tacit assumption that a rational discussion must have the character of a justification, or of a proof, or of a demonstration, or of a logical derivation from admitted premises. But the kind of discussion which is going on in the natural sciences might have taught our philosophers that there is also another kind of rational discussion: a critical discussion which does not seek to prove or justify or establish a theory, least of all by deriving it from some higher premises, but which tries to test the theory under discussion by finding out whether its logical consequences are all acceptable, or whether it has, perhaps, some undesirable consequences."

80. The theory of the theory-loadedness of abservation is contradicted by evidence of theory-resistance of observation in the psychology of perception. For instance, even if we know that the moon at the horizon is not bigger than the moon at its zenith we still perceive it as bigger. Moreover, this theory often goes together with a false notion of science, namely that the theories on the functioning of an experimental apparatus and the side-conditions of an experiment are so closely connected to the theories which are tested by that experiment, that there results an inescapable circle. Normally, however, both theories are miles apart. This is very obvious in biology and medicine. The experimental apparatuses are built on the basis of physics and computer science, but the theories tested in the experiments are biological, and no one would say that the results of biological research were determined by physics or computer science. 
little children do this on a daily basis, and are constantly inventing new principles and categories. We don't see why mentally flexible adults shouldn't be able to do the same.

A glance at the intellectual sources of framework-relativism reveals that it-inter alia-relies on a partial reading of Thomas $\mathrm{Kuhn}^{81}$ and on some sloppy scholarship of Benjamin Whorf. The framework-theory holds that there is no real communication among people arguing on the basis of incommensurable frameworks. And where there is no communication, no rational assessment of the position of the Other can be made. Precisely this was the conclusion drawn by many philosophers from Thomas Kuhn's seminal essay "The Structure of Scientific Revolutions" of 1962. However, Kuhn explicitly rejected this reading of his work in the 1969 postscript to the second edition. Kuhn thought that paradigms (i.e. frameworks in our sense) are able to be transgressed and that the problems of translation between paradigms can be resolved in principle. ${ }^{82}$

The belief that categories contained in language constitute an insurmountable framework is inspired by linguist relativism. Generally, linguistics plays a big role in post-modernist thought. A key postmodernist assumption is that all human systems operate like language and that there is nothing prior to language. ${ }^{80}$. Law (like language) is viewed as a complex, coded system of signs, which is powerful but finite and which constructs and maintains meaning and value. Consequently, the chosen complementary science of post-modern legal comparison is no longer (as for the traditionalists) social science, but rather literary theory. ${ }^{84}$ The most prominent protagonist of linguist relativism in the 20th century has been Benjamin Whorf. Whorf told us about the language of the Hopi Indians, a Native American tribe in Arizona: "After long and careful study and analysis, the Hopi language is seen to contain no words, grammatical forms, constructions or expressions that refer directly to what we call 'time', or to past, present and future, or to enduring or lasting ... [T] he Hopi language contains no reference to 'time', either explicit or implicit". ${ }^{85}$ Whorf's conclusion was that the Hopi lived in a universe totally different from ours, because they lacked the concept of time. The

81. See, e.g., references to Kuhn in Ainsworth supra n.10 at p.30; or in Rosa supra n.72 at pp.12-17.

82. Thomas S. Kuhn, The Structure of Scientific Revolutions, (3rd Ed. 1996) at pp.198-204.

83. Ermarth supra n.11 at p.588.

84. A paradigmatic example is Mitchel de S.-O.l'E. Lasser, "Comparative Law and Comparative Literature: A Project in Progress", (1997) Urah L.Rev. 472-524, constructing and deploying a "literary theory' methodology in order to analyze the complex significations produced by the French and American judicial discourses" (idem. at p.471); see also the extensive footnote in Grosswald Curran supra n.6 at pp.49 n.12 and $54-59$ ("Comparative Law as a Phenomenon of Translation").

85. Benjamin Lee Whorf, "An American Indian Model of the Universe", Manuscript approx. 1936, in John B. Carroll (Ed.) Language, Thought, and Reality: Selected Writings of Benjamin Lee Whorf (1956) 57, at pp.57-58. 
Whorf theory received widespread attention. Less known is Ekkehart Malotki's meticulous study of the Hopi language, which unearthed a lot of words, grammatical forms, constructions and expressions referring to time, as indicated in the following translation of a Hopi utterance: "Then indeed, the following day, quite early in the morning at the hour when people pray to the sun, around that time he woke up the girl again." 86

Here we are tempted to ask: couldn't this classic case of scientific error have occurred in comparative law as well? It teaches us that seemingly incommensurable differences may be merely a scientific artefact due to lack of a more complete knowledge and understanding of a foreign legal order and its culture.

\section{Objections against Moral Relativism}

Up to now, we have spoken of knowledge and values together, but have concentrated on epistemic relativism. We now want to discuss moral relativism in particular. According to moral relativism, principles of justice, fairness or equity are merely a function of moral practices, which in turn are entirely contingent (for example to culture, history or society). Any type of morality is as justified as any other. Therefore no external standard of justice can be applied to a given legal instrument. It is impossible to pass a judgment on the morality of legal practices of others who have adopted moralities different from one's own. ${ }^{87}$

Culture-based moderate moral relativism appears to be an appropriate attitude vis-d-vis our pluralist, divided, multi-cultural world. But its strict version is not viable. The simplest reason is the one already mentioned, that cultures have no clear boundaries. Another argument against moral relativism is its tendency to contradict itself. A world-wide discourse on moral relativism is perhaps not a contradiction in and of itself, ${ }^{88}$ as a discourse on epistemic relativism is. One can, however, quickly entangle oneself in contradictions, namely if one sets up rules for that discourse and does not allow participants to act in a manner which is unfair,

86. Ekkehart Malotki, Hopi Field Notes (1980), quoted in idem, Hopi time: A Linguistic Analysis of the Temporal Aspects in the Hopi Language (1983) at p.vi.

87. Interestingly enough, moral relativism is often defended in a philosophical camp which otherwise contrasts with post-modernism in most respects, the communitarian one. Communitarians emphasise that moral intuitions, capacities and reactions are created and determined through upbringing and education in concrete communities. See in particular Alasdair MacIntyre, After Virtue (1984); also Charles Taylor, Sources of the Self, 1989, Chapter 1, entitled "Inescapable Frameworks", pp.3-24.

88. But see Karl-Otto Apel, Transformation der Philosophie, Vol. II: Das Apriori der Kommunikationsgeneinschafi (1973), esp. 400, 420-425; Jurgen Habermas, "Diskursethik-Notizen zu einem Begrandungsprogramm", in idem, Moralbewußtsein und kommunikatives Handeln (1983), 53, at p.105; Jilrgen Habermas, "Erlauterungen zur Diskursethik", in idem, Ertäuterungen zur Diskurseshik, 2nd ed. (1992), 119, at p.195 for the assertion that engaging in a discourse necessarily implies recognition of some universal norms. 
libellous, insulting, plagiarious etc. Thereby one asks for some universal set of moral rules and thereby contradicts the relativist stance.

In practice, culture-based moral relativism pays a high price, because it can be made the handmaiden of dictators and stabs human rights activitists in the back. Most people assume that some basic human rights apply in the whole world, and dictators increasingly show a bad conscience if they violate them. In defence they can, however, make use of moral relativisms and have often done this, by asserting that certain values are culture-bound values, for example western values, which do not apply in their own culture. Dissidents and human rights proponents in the respective countries have always protested and pointed to the hypocrisy of this reasoning. ${ }^{99}$ Here, post-modernism finds itself in the embarrassing role of an intellectual assistant to dictators.

Put the other way round, moral relativism, strictly applied, would forbid all intercultural argument or action against totalitarian and inhuman ideologies. Everyone who is engaged, everyone who takes any political action whatsoever, be it as a human rights activist or otherwise, negates moral relativism through his very actions. ${ }^{90}$

But, if we reject moral relativism, does not the spectre of moral absolutism arise? No. First of all, moral framework-relativism itself is a moral absolutism, for it treats certain values within a given framework as absolute and does not allow for escape. It seems to be less absolutist and more realist to assume that people can make moral experiences which force them to step out of the moral framework they are used to. On the basis of that assumption, we suggest a strategy that tries to ascertain the validity of norms empirically with a view to actual moral attitudes of people. We expect to find some basic attitudes to be very similar in almost all people. But this finding would not be a moral absolutism based on $a$ priori reasoning, but a moral ex post universalism based on empirical data.

Moreover, ultimate moral decisions are not needed in comparative law, because a comparatist normally asks meta-questions on moral issues, which in turn belong to the epistemic, not moral sphere: to determine whether a specific legal tool is fair according to the standards of its own legal culture (or any other standard applied by the scholar) is no moral statement, instead it is an epistemic one which may be true or false. Comparative law is, therefore, ultimately independent of the question of whether or not moral relativism is true.

89. See, e.g., Lung Jingtai, "Wo Respekt zu Gleichgultigkeit wird”, (1998) No. 78, 2 April, Frankfurter Allgemeine Zeitung 39.

90. See for further arguments against moral cultural relativism and for a "deliberative universalism" Amy Gutmann, "The Challenge of Multiculturalism". (1993) 22 Political Ethics, Philosophy \& Public Affairs 171-206. 


\section{The Comparatist's Bias}

\section{a) The Post-modernist Argument}

Post-modernists assert that even if we explicitly abstain from evaluating, our whole investigation and presentation will be full of (unconscious) judgements. ${ }^{11}$ We are unavoidably biased, so that any attempt at a neutral description is an illusion, merely covering up our own-most Eurocentric (or Western) - views: we are subject to "the unconscious spell that holds us to see others by the measure of ourselves", ${ }^{92}$ we wear "lenses" that are "superimposed on foreign legal systems" and "may cause severe misperceptions and disclocations". 93 "Comparatists cannot hope to perceive beyond the limits of their perceptions, nor to divest themselves entirely of the substructural categorisations of their own cultures of origin." Comparative law "is a project that is perhaps inherently ethnocentricthere is no way to escape or transcend the ethnocentric gaze." "In other words, there is always a Vorverständnis, which is creative or "(virtually) always and already normative", for "the context and legal unconscious already perform normative work in selecting, establishing, and organizing the so-called 'descriptive' categories deployed in legal thought."

Bias is already inherent in the choice of what materials deserve comparison (which includes the implicit, foundational comparison which indicates whether the materials are sufficiently similar to be meaningfully

- compared in depth) and is "almost always more or less arbitrary or

91. "The questions comparativists ask will reflect their own perceptual prisms and affect their receptivity to data from observed legal cultures". Grosswald Curran supra n.6 at p.58. "One of the dangers of comparative law is the temptation to mould the data with a view to substantiating a preconceived thesis. This temptation is exacerbated by the fact that the legal material which comparative research provides is extremely diverse and malleable." Hill supro n.3 at p.107.

92. Frankenberg (1985) supra n.4 at p.414.

93. Demleitner supre n.9 at p.654; Grosswald Curran supra n.6 at pp.48-49 (distortion inevitably prevails in the comparative act).

94. Grosswald Curran supra n.6 at p.58. The American legal anthropologist Rebecca French reminds the comparatist of "all the practical and conceptual assumptions that American lawyers already know about the world and about the law: the dimensions of space and time, the subtleties of legal myth and narrative, the legal rituals that define how actors act, speak, and move in a legal forum, social hierarchies that influence their decisions, the aspects of authority, power and legitimation they understand. But what if most of or all of these practical and conceptual assumptions were not only different from those that apply in Tibet but arranged in networks or sets or relations that were also entirely different? What if, when one first asked Tibetans about law, they said that no such category existed?" Rebecca Redwood French, The Golden Yoke: The Legal Cosmology of Buddhist Tibet (1995) at p.57. French's marvellous book is a highly impressive attempt to understand a very different legal culture.

95. Crossman supra n.72 at p.526.

96. Pierre Schlag, "Normativity and the Politics of Form", (1991) 139 U. Pennsylvania L.R. 801 at pp.808 and 812 . 
one-sided, leaving quite a lot of room for permeation of subjectivism". ${ }^{97}$ "[T]he conceptual constructs that we use determine the way in which we perceive the subject we are studying, and consequently the issues that we imagine to be worth investigating".98

The Vorverständnis also determines the choice of the aspect under which we compare. It is derived from observations in the comparatist's own culture-so the critical stance-and then styled as an abstract tertium comparationis. Because the tertium is basically a cultural projection, comparison under that aspect becomes a "self-fulfilling prophecy".99

\section{b) Refutation}

The bias-argument feeds on the premise that there are closed frameworks. The "unconscious spell", the "lenses", "the ethnocentric gaze" etc. denote frameworks. We have rejected the premise of inescapable frameworks and need not repeat ourselves here.

The bias-argument is self-defeating in at least two ways. First, in order to raise the bias-reproach, post-modernist critique must be able to occupy a position beyond the frameworks. Otherwise it could not recognise the bias. But transcending the framework is what the critique cannot do according to its own theory. Secondly, in order to be consistent, it would have to conceive of itself as bias and projection and self-fulfilling prophecy of its own framework. This, however, would again be self-defeating.

The popular reproach that the scientific community is westerndominated and western-biased ${ }^{100}$ deserves special and explicit refutation. Apart from the fact that boundaries between the West and the East or the South are blurry, ${ }^{101}$ the argument can be used in all situations to devaluate undesirable results. A consensus among comparatists can be questioned on the ground that it exists among western scholars only. But if non-western scientists agree, it can be suspected that their voices have been, through education and power structures, westernised and not authentic. We here have an argument ad personam (not ad hominem), ${ }^{102}$ which is banned in science. The western-bias argument can be used to refute whatever hypothesis. Its critical potential is, therefore, zero.

97. Roman Tokarczyk, "Some Considerations on Comparative Law", (1990) 59 Revista Juridica Universidad de Puerto Rico 951 at p.959.

98. Ainsworth supra n.10 at p.30, see also Legrand (1999) supra n.62 at pp.1054, 1057-58. 99. Joachim Matthes, "The Operation Called 'Vergleichen'", in idem (Ed.), Zwischen den Kulturen? Die Sozialwissenschafien vor dem Problem des Kulturvergleichs (1982) 75 at p.83.

100. See, e.g., Frankenberg (1997) supra n.3 at p.263.

101. Supra pp.820-821.

102. See Chaim Perelman \& Louise Olbrechts-Tyteca, The New Rhetoric: A Trearise on Argumentation (1969) (John Wilkinson and Purcell Weaver transl.) (orig. 1958) at pp.111-112. 
The alternative to the bias-argument is an undogmatic case-by-case critique, which allows for the possibility of non-biased research. Projections, unconscious judgements, self-fulfilling prophecies are possible everywhere, but to assert that they are inevitable in comparative law is merely unscientific, critique-immune dogmatism.

\section{Comparative Law as a Hegemonial Project}

a) The Post-modernist Argument

The view that knowledge and understanding is framework-dependent is complemented by the post-modernist focus on power ${ }^{103}$ and the Other ${ }^{104}$ : Because there is no truth, there is also no search for truth, but only ideology. So legal scholarship is, as law in general, basically an ideology, a theoretical construct for the purpose of gaining, cementing, and justifying the exercise of power, ${ }^{105}$ which means in particular domination and discrimination of the Other. The entire process of comparative law is not really a comparison of two realities, but an appropriation of the Other according to the familiar standard, ${ }^{106} \mathrm{a}$ "power-oriented nostrification of the foreign". ${ }^{107}$ Hence, comparison proceeds along an imagined trajectory of social or cultural "development" and is in this regard still influenced by the after-effects of 19 th century evolutionism. ${ }^{108}$

103. The power theme has been primarily developed by Michel Foucault. See as an overview the interview with Foucault: "Wahrheit und Macht" (Truth and Power), in Michel Foucault, Dispositive der Macht: Uber Sexualitut, Wissen und Wahrheit (1978) 21-74.

104. Cf. Jean-François Lyotard, "Réponse à la question: Qu'est-ce que le postmoderne?," (1982) Vol. 37, No. 419 Critique: revule genérale des publications françaises el érangères 357, German transl:: "Beantwortung der Frage: Was ist postmodern?," in Peter Engelmann (Ed.), Postmodeme und Dekonstruktion (1990) 33 at pp.48-49 on unrepresentability and difference; Jean-François Lyotard, Un enjeu des utres des femmes (1976), German translation: "Ein Einsatz in den Kampfen der Frauen", in idem, Das Patchwork der Minderheiten (1977) 52-72. Consequently, the new vision of comparative law has its "focus on difference" (Grosswald Curran supra n.6 at p.83).

105. See, e.g., Schlag supra n.96 at pp.803-804. Human rights law is, in critical eyes, "not based on innocent humanitarianism, timeless and universal Truth. Rather, is a situated, contingent, and contested knowledge that is discursively produced by multiple dominating and resistant discourses. In its current form, human rights law naturalises and legitimises the subjugating and disciplinary effects of European, masculinist, heterosexual and capitalist regimes of power." Dianne Otto, "Rethinking Universals: Opening Transformative Possibilities in International Human Rights Law," (1997) 18 Austral. Yearbook Int'l L. 1 at p.35.

No wonder that traditional comparatists are deemed to share a "status-quo orientation and a fairly uncritical acceptance of the ideological foundations of the hegemonic legal regimes". Frankenberg (1997) supra n.3 at p.266. Berman advises critical comparatists to "refuse the homogenizing and essentializing gestures of the tradition: instead, show how all cultural formations are split, hybrid, and embedded in contexts of power". (Berman supra n.4 at p.281).

106. Matthes supra $n .99$, at p.84.

107. Jürgen Straub, Handlung, Interpretation, Kritik: Grundzuge einer textwissenschaftlichen Handlungs. und Kulturpsychologie (1999) at p.6.

108. Matthes supra $n .99$ at pp.81-82. 
This leads to the claim that traditional comparative law is an ideological project, obeying a secret (or unconscious) political agenda which is a "hegemonic" 109 one. The hegemonic reaction towards the Other is either assimilation ("normalization") or exclusion ("exoticization"), ${ }^{110}$ both alternatives ultimately seeking to perpetuate the supremacy of European elites. Critical comparatists find that traditional comparatists will pursue either one of these evil strategies." "Traditional comparative activities are "political interventions", 12 "politics in the guise of comparative science", 113 and "an invasive political enterprise"." ${ }^{114}$ Comparative legal scholarship is not so much an intellectual enterprise as essentially an "ideological project, developing lenses through which the center will interpret the periphery,... developing the alternatives of assimilation and exclusion for particular cultures while solidifying an ideological picture of international governance 'above' cultural differences, either absorbing or avoiding them." 115 Mainstreamers are, first, uncritical towards the legal status quo in their country, and towards the ideological foundations of Western legal systems: "[T]he comparative law agenda is largely conditioned by an uncritical attitude towards fundamental issues of social and economic organization." 116 Therefore, they "almost inevitably reach conclusions which are conservative-in the sense of confirming and consolidating existing preconceptions about law and society". 17 Secondly, mainstreamers are "partial to unity and standardisation under the auspices of the very rule of law [they] like [...] best." Their vocabulary, goals, method, and discursive practices betray a strong bias for the home law. But they try "to suppress their subjectivity and hide their peculiar perspective behind the rhetoric of objectivity and neutrality, while

109. See Frankenberg (1997) supra n. 3 at p.263 on the mainstreamer as a "hegemonic self, a representative of legal paternalism".

110. Berman supra n.4 at p.282.

111. See idem, passim; Kennedy supra n.1 at p.618; Esquirol supra n.68 at p.470, on comparatists" "fiction of Europeanness" of Latin American Law.

112. Frankenberg (1997) supra n.3 at p.261. See similarly Hill supra $n .3$ at pp.109-110 on the pervasive influence of the political climate of the time on comparative scholarship.

113. Esquirol supra n.68 at p.437. Esquirol seeks to show that Rene David's descriptions of Latin American law "are subordinate to a politico-theoretical project" (idem at p.438).

114. Frances Olsen, "The Drama of Comparative Law", (1997) Utah L.Rev. 275 at p.278. "Comparativists should recognize the power relations involved" (idem).

115. Kennedy supra n.1 at p.619. According to Kennedy, the comparatist's modest posture as expert or erudite reinforces the internationalist's claim to govern for a space beyond culture. By dividing the assimilable from the exotic, the comparatist stabilises the boundaries between centre and periphery while reinforcing the claim that those boundaries are matters of culture and history rather than political products of an ongoing international regime. "The comparativist, in this sense, works as an ideologist for the global system of government", idem at p.636.

116. Hill supra $n .3$ at p.106, also p.107.

117. "[T]he comparative law agenda is largely conditioned by an uncritical attitude towards fundamental issues of social and economic organization." Hill supra n.3 at p.106. 
camouflaging their politics by pragmatism." ${ }^{118}$ They have a "paternalistic agenda", "a totalizing grasp of the subject matter" and work "to enhance and spread the authority of Anglo/European law". ${ }^{19}$ In short, they pursue a "project of neocolonialism". ${ }^{200}$ The traditional methods and techniques of comparison are, therefore, "strategic". ${ }^{21}$ They serve to justify and confirm the superiority of western law and the necessity to intervene. ${ }^{122}$

Legal harmonisation is "part of a new interventionist political scheme"123 as well, and the current rush for codification appears as a "form of conquest executed through legal transplants and harmonization strategies ... dictated by the European Community, the IMF, the World Bank, the Asian Development Bank, and other supranational or international agencies." 124

Concentrating on "Power" and the "Other", critical analysis seeks to uncover patterns of subjugation and discrimination in legal institutions. Often, critical comparatists study legal cultures which have been or still are dominated and marginalised, such as former colonies, developing countries, or countries of the former socialist bloc, which in their eyes undergo new forms of legal domination exercised by capitalist legal consultants and market forces. Much critical comparative work centres upon the dichotomy between dominant western law and non-western law.

\section{b) Refutation}

The hegemony-argument holds that comparatists do not care for truth, but primarily for power. It also implies that we cannot distinguish true from false statements. The hegemony-argument is thus based on epistemic relativism, whose viability we have already contested.

Moreover, the argument is self-defeating in a specific way: If there is no truth, but only ideology to camouflage aspirations to power, then even the post-modernist critique cannot claim to be true but can only consider itself as an ideology to camouflage aspirations of power. Thereby it would exclude itself from the scientific discourse.

Certainly comparative scholarship may be motivated by hegemonial pretensions and may constitute a political intervention cloaked by pseudo-scientific methods, but not inevitably. One must examine every individual piece of scholarship to see whether it is so.

118. Frankenberg (1997) supra n.3 at p.263.

119. Idem at $\mathrm{pp} .263-265$.

120. Esquirol supra n.68 at p.437 on Rene David's writing on Latin America.

121. Frankenberg (1985) supra n.4 at p.421.

122. Frankenberg (1997) supra n.3 at pp.265-266.

123. Idem at p. 273.

124. Idem at p.262. 


\section{Comparatist Categories and Classifications}

\section{a) The Post-modernist Argument}

Under the premise that logic and science heavily depend on specific epistemic frameworks with relative validity, all types of (scientific) categories, taxonomies, and classifications are suspicious. ${ }^{125}$

A prominent illustration of this suspiciousness is Michel Foucault's citation of a taxonomy from "a certain Chinese encyclopaedia", reported by Jorge Louis Borges. ${ }^{126}$ In it, animals are regrouped as follows: a) animals belonging to the emperor, $b$ ) embalmed ones, c) tamed ones, d) sucking pigs, e) sirens, f) mythical ones, g) stray dogs, h) those included in this classification, i) those acting as if mad, $j$ ) innumerable ones, $k$ ) those drawn with a very fine brush of camel hair, 1) and so on, $m$ ) those having just broken the flower vase, $n$ ) those looking like flies from far. This strange and irritating order has, through Foucault, become a prime example of non-western categorisation, by which Foucault apparently wants to remind us of the relativity and cultural embeddedness of our (western) modes of ordering things, laws, institutions. ${ }^{127}$

The mistrust of classifications is particularly relevant in comparative law, which has traditionally counted classification (for example, in legal families) to its tasks. ${ }^{128}$ The critique finds that current comparatist classifications are merely "formalist ordering and labeling ... often randomly gleened [sic!] from limited data". ${ }^{29}$ Classification is EuroAmerican-centric, banning to a "residual category such as 'other', 'immature', 'primitive' ... 'developing', 'in transition'" all non-westęrn laws. ${ }^{1.0} \mathrm{Critical}$ comparisons should, rather, unearth "substructural, often unarticulated, categorisations" in order to "challenge silent assumptions". ${ }^{131}$ Ultimately, post-modernists are fond of calling into question the category of law. ${ }^{132}$

125. See, e.g., Grosswald Curran supra n.6 at p.48.

126. Jorge Louis Borges, "Die analytische Sprache John Wilkins' " in idem, Das Eine und die Vielen: Essays zur Literatur (1966) 209 at p.212 (first published in Historia de la eternidad, 1953).

127. Michel Foucault, Les mots et les choses (1966) (p.17 of the German translation, Die Ordnung der Dinge, 14th ed. 1997).

128. See for a moderate criticism of the doctrine of legal families Kotz supra n.5S at pp.493-505; for a new taxonomy Ugo Mattei (1997) 45 Am.J.Comp.L. 5-44 (suggesting the division of the world legal systems into the three families of the rule of professional law, the rule of political law, and the rule of traditional law).

129. Frankenberg (1985) supra n.4 at p.421.

130. Frankenberg (1997) supra n.3 at p.267.

131. Grosswald Curran supra n.6 at p.45.

132. See Grosswald Curran supra n.6 at p.59, whose "immersion approach" to comparative law "suggests that law does not have a life of its own". See also French supra n.93 at pp.xiii and 57 . 
b) Discussion

The post-modernist claim that categories and classifications are culturally contingent is a direct outgrowth of the theory of inescapable cultural frameworks. Classifications of laws, institutions, and legal orders are doomed to misrepresent the foreign law and are inevitably subjective and arbitrary only under the premise that frameworks are insurmountable, a premise that we have rejected.

Foucault's famous passage does not convince us of anything else. Foucault leaves the reader under the impression that the Chinese taxonomy is authentic, and we do not know whether he himself believed in its authenticity. The Chinese order is, however, purely fictional, an invention of Louis Borges himself, hence a "western" idea. ${ }^{133}$ Some may consider this literary construction as yet another manifestation of preconceived notions of ostensibly "Asian" logic, which we share when we adopt Borges' artefact as historically correct. Others may, on the contrary, take Borges' ingenious invention as a proof that Borges was able to transgress his (western) confines. In any case, being a fiction, the "emperor's order" cannot authentically illustrate the complete cultural relativity of classifications.

Classification (for example, into legal families or cultures) is the result of a comparison under one or several aspects. Put differently: classification means to highlight some (common) aspects and to leave aside others. The aspects of comparison are pre-selected, but are eventually adjusted in the process of comparison. ${ }^{1.34}$ So in comparative law, classifications are, as elsewhere, no apriorical givens, but attempts of ordering. Again, a moderately critical approach is more helpful than framework-thinking: we must be aware of the fact that categories and classifications may differ in different cultures, at different times, and we must realise the ensuing danger of establishing taxonomies that do not adequately reflect important features of legal systems. Also, we need to question traditional classifications and dig out unarticulated and latent ones. But all this does not mean that an outsider can never understand foreign categories and classifications and translate them (approximately) into his own categories and classifications, nor does it preclude the possibility of discovering or inventing suitable and fitting ones.

133. See Umberto Eco, La ricerca della lingua perfetta nella cultura europea (4th ed. 1993) at p.222; Jingtai supra n.89.

134. For example, a macro-comparison (and classification) can be undertaken with regard to the aspect of valid legal sources. This aspect of classification will furnish two classes: codified (statutory) law and uncodified, judge-made law. Other possible aspects of classifying legal systems may be the systems' concept of law, the legal methods applied, the style of legal thought, or the dominating type of lawyers, the leading theory of interpretation of law, the leading theory of legitimation of law, and so on. 


\section{Functionalism}

\section{a) The Post-modernist Critique}

The post-modernist critique of functionalism, coined as "better-solutioncomparativism", ${ }^{135}$ is primarily directed against its implied or outspoken universalism, its "agenda of sameness". ${ }^{136}$ In the critical view, functional resemblances belie deep "disagreements of instinct and inclination in reasoning about legal problems"; $; 37$ there are only "chimerical universal social functions". ${ }^{138}$ "The focus on functionalism is suited to yielding results of similarity because it does not stray away from the surface level of functional results to legal problems to societal, historical, and cultural underpinnings" writes Vivian Grosswald Curran, and she argues-not unconvincingly - that the emigre generation of comparatists purposely privileged findings of sameness and underestimated the significance of reasons because of their personal experience with the Nazi regime, which had denied human sameness and practised the Shoa. ${ }^{139}$

The critique also rejects the functionalist claim to objectivity and neutrality. It holds that the intellectual process, by which the functions of legal institutions are identified and by which legal institutions are compared and evaluated, is inescapably subjective, personal, and contestable.$^{140}$ In this view, functionalism is disguised as apolitical, but in reality "fundamentally conservative, because its emphasis on points of detail avoids more challenging and radical questions about the role of law in society." 141

\section{b) Discussion}

As far as the post-modernist approach eschews functionalism on the ground that it is inescapably subjective and only seemingly technical and apolitical, it merely repeats the bias- and the hegemony-arguments in terms of a critique of functionalism. We have already discussed these two arguments.

The assertion that the functional approach underestimates fundamental differences (in legal reasoning, legal culture, societal underpinnings etc.) flows from framework-thinking, according to which legal thought,

135. Frankenberg (1997) supra n. 3 at p.263; see already Hill supra $n .3$ at p.106.

136. Grosswald Curran supra n.6 at p.61.

137. George P. Fletcher, "The Universal and the Particular in Legal Discourse", (1987) Brigham Young University L.R. 335 at p.350.

138. Kennedy supra n.1 at p.590 n.76.

139. Grosswald Curran supra n.6 at pp.53, 66-78, quotation at p.66 n.76.

140. Hill supra n.3 at p.104. See also Kennedy supra n.1 at p.561 (pointing out that functionalism has claimed to be an objective strategy, a way of avoiding the temptation to subjective judgement and premature closure).

141. Hill supra n.3 at p.107. 
language and judgement are determined by greatly differing and ultimately irreconcilable frameworks. We have rejected this theory.

The post-modernist claim that functionalism is superficial is justified to the extent that the functional approach (narrowly conceived) tends to overstate the quality of law as a rational response to social problems. ${ }^{142}$ But realising that law serves manifold other purposes does not force us to say that "function" in its ordinary sense does not matter or that looking at "functions" is misleading.

Law functions, for instance, as a rhetorical practice that "tells stories about the culture that helped to shape it and which it in turn helps to shape", and through which "social data are imaginatively reconstructed as legal facts and concepts." 143 Law may run counter to specific social needs or interests or may not make a difference..$^{14}$ It is, therefore, important to take into account the moral and political aspects of laws that may not function as social problem-solvers but which have completely different, even antagonist functions.

Because of the multiplicity of legal functions, which may be situated on very different levels, and which differ from culture to culture, the so-called functional approach is not as easily applicable as some functionalists like to believe and does not produce simple and unambiguous results. ${ }^{145}$ The numerous functions of the law (political, technical, social, rhetorical, religious, spiritual, symbolic etc.) may be difficult to detect and must be weighed in importance. In the absence of "the" function of law, functionality depends on the viewpoint taken. Even if we look only at the technical surface-level, we will find that a rule may be laudable with respect to its technical perfection, its enforceability, its efficacy, its compatibility with other features of the legal system or the legal security it produces. As Myres S. McDougal once pointed out: "The demand for inquiring into function is, however, but the beginning of insight. Further questions are 'functional' for whom, against whom, with respect to what values, determined by what decision-makers under what conditions, how, with what effects." 146

142. This objection has been forcefully raised by Alan Watson, Legal Transplanis: An Approach to Comparative Law, 2d ed. (1993), esp. at pp.107-118. Watson discovered an extensive and important practice of legal borrowing. If law on a large scale can be borrowed from a very different place and survive to a very different time, then there can be no simple relationship between a society and its law, he concludes.

143. Glendon supra n.40 at pp.8-9. See also Fletcher's critique of functionalism, advocating an approach that takes the legal discourse and its linguistic particularities as the starting point of analysis, not superficiai functional resemblances supra n.139 at pp.335-351.

144. Frankenberg (1985) supra n.4 at p.437; D. Kokkini-Iatridou, "Some Methodological Aspects of Comparative Law", (1986) 33 N.I.L.R. 143 at p.160.

145. Watson supra $n .142$ at p.4; Hill supra $n .3$ at p.198; see Grosswald Curran supra $n .6$ at p.71 n.93 for an example.

146. McDougal supra n.53 at p.219. 
To compare laws under the aspect of economic efficiency is not more "objective" than comparing them under the aspect of social function. The difference is that economic efficiency is a narrower criterion, referring to the particular economic function of a law. Comparative assessments under the efficiency-aspect may therefore be quite specific and precise. However, those aspects of an issue which are easiest to measure are not necessarily the most important ones. To focus on economic efficiency as the exclusive criterion under which to evaluate laws (as the strict law and economics approach does), and consequently to compare laws exclusively under that aspect, reveals a quite reductionist view of the law and its role in society.

\section{Towards a Post-Post-Modernist Comparative Law}

A post-post-modernist approach to comparative law will retain the (self-)critical impetus of the post-modernist critique, reject the postmodernist assertion that objectivity is not attainable in comparative law, and synthesise old and new demands for interdisciplinarity and thoughtful hermeneutics.

\section{With Post-modernism: Heightened Reflexivity}

The post-modern critique of comparative law correctly asks for highly self-conscious and self-critical methodological guidance and for overall heightened reflexivity.

This first of all suggests the conscious integration of various perspectives and an attentiveness to hidden purposes, meanings, themes, conceptual building blocks and strategies in legal texts pertaining to different cultures. ${ }^{147}$

Secondly, heightened reflexivity comprises an awareness of the relationship beween one's research and the Zeitgeist: the comparatists' themes, goals and approaches are shaped by broad intellectual or theoretical trends and movements, by societal developments and the political climate. We have mentioned that 19 th century historicism and its nationalist outgrowths have influenced comparative law. Subsequently, unificatory enthusiasm of the first half of the 20th century was at least in part a reaction to the atrocities of the First World War and an attempt to contribute to the efforts of the League of Nations. Socio-functionalism in comparative law is only one manifestation of the rise of functionalist approaches in many disciplines, beginning with psychology and sociology. Finally, the current revitalised interest in harmonisation and unification has to do with needs created by globalisation and European Union-

147. See for a great example of scholarship French supra $n .94$ (on the methodological aspects mentioned here at pp.16, 59). 
building. Awareness of these links helps the comparatist to check his questions and his answers.

Thirdly, the post-modernist critique of comparative law has rightly underlined the critical potential of comparative legal studies and their suitability to uncover the extent to which the form and substance of any legal system result from the implementation of moral and political values. ${ }^{148}$ Comparative legal studies are an operator of critique, because they help to create a critical intellectual distance from one's legal system, forcing us into sympathetic yet critical knowledge of law in another context, disrupting our settled understandings, and provoking new judgements. ${ }^{149}$ However, this is no new insight, and it has been emphasised in many standard textbooks of comparative law. ${ }^{150}$ It is beautifully captured in Mary Ann Glendon's description of "Comparative Law as Shock Treatment". ${ }^{151}$

\section{Against Post-modernism: Objectivity through Mutual Critique and Intercultural Division of Labour}

Of course, the entire comparative process is full of explicit or implicit choices. The researcher's choice of materials to compare, and of aspects of comparison/evaluation may depend on political motives, or on other personal preferences. It always depends on the researcher's personal store of knowledge, and on the specific objective of research, such as political intervention, improvement of domestic law, regional harmonisation, mere curiosity etc. Finally, the researcher's choices are likely to be influenced, as just pointed out, on scholarly trends and traditions.

To that extent, comparison and evaluation is tentative, segmented and fragmented. But this is inevitable, because every scholar and every

148. See, e.g., Hill supra n.3 at p.115.

149. See only Paolo Carozza, "Continuity and Rupture in New Approaches to Comparative Law", (1997) Utah LRev. 657 at p.663; Mathias Reimann, "Stepping out of the European Shadow: Why Comparative Law in the United States Must Develop Its Own Agenda", (1998) 46 Am.J.Comp. L 637 at p.645. According to Frankenberg (1997) supra n.3 at p.270, comparative law needs "[t]he recognition of the law school as an exotic place, and of comparative legal work as an exotic practice". Brenda Crossman suggests "turning the gaze back upon itself" as a comparative methodology to "make explicit the seemingly inescapable risk of ethnocentrism in the comparative project, while at the same time, deploying the comparison to challenge that ethnocentrism" (Crossman supra n.72 at p.537).

150. See only Schlesinger el al. supra n.54 at p.39: "To combat an unperceptive and uncritical attitude toward one's own law is indeed one of the main objectives of teaching Comparative Law".

151. Mary Ann Glendon, "Comparative Law as Shock Treatment: A Tribute to Jacob W. F. Sundberg", in Erik Nerep \& Wiweka Warnling-Nerep (Eds.). Sartryck ur: Festskrift till Jacob W. F. Sundberg (1993) 69 at p.69. 
scientist has to make those or similar choices and cannot investigate everything under every aspect. ${ }^{152}$

The necessarily fragmented and "subjective" comparison may be ill-founded, self-fulfilling, biased, superficial, imprecise, faulty, etc. However, this does not-contrary to the post-modernist belief-damage comparative research as a whole. It is a truism in the philosophy of science that "science and scientific objectivity do not (and cannot) result from the attempts of an individual scientist to be 'objective', but from the co-operation of many scientists". ${ }^{153}$ So scholarship escapes the prejudice of the point of view of those constructing it through testing and mutual criticism. ${ }^{154}$ In comparative law, the results will very likely become sound in the long run, if criticism comes from all investigated legal cultures. ${ }^{155}$

A more pragmatic, sociological explanation why discussion and critique of comparative research really works lies in the division of labour within the scientific community, which is perhaps the most important factor of success of modern science and scholarship. It is simply more effective when everybody does not try to discover everything, but instead researches a small field thoroughly. This division of labour will function only if different researchers make use of each others' findings and build on them. When one scholar considers the results of another researcher, she will often realise that his results are incompatible with her own findings, and that the different research results cannot be put together to create a whole picture. In this case the researcher will try to discover the causes of this discrepancy, and she will do so by discussion, critique and scrutiny. The point is: mutual critique and scrutiny naturally flows from the division of labour because it occurs in every attempt to use others' results for own research. ${ }^{156}$

152. This is no excuse for comparative projects that are too narow. In a largely unexplored field, it is certainly better to have a great diversity of aspects of comparison and to take them out of different fields instead of restricting oneself to one narrow aspect, e.g. economic effliency. So over-specialisation may be counter-productive as well.

153. Karl R. Popper, The Open Society and lis Enemies (1950) at p.403. See with regard to comparative law Ernst Rabel, "Deutsches und amerikanisches Recht", (1951) 16 Zeirschrift fur auslandisches und internationales Privatrecht (RabelsZ) 340 at p.359: "What remains of the coloring of the picture by origin andeducation of the scholar, will be corrected by international co-operation."

154. Popper calls this "the idea of mutual rational control by critical discussion". Karl R. Popper, The Logic of Scientific Discovery (1992) at p.44 n.1.

155. The post-modemist critics' objection is that discussion and rectification is a lure, because no real communication and collaboration is possible among scholars from different cultures (Grosswald Curran supra n.6 at p.66 n.76: "a Tower of Babel is the more logical outcome of international collaboration ${ }^{n}$ ). But to deny the possibility of communication is again mere framework-thinking and a good shield against competition and critique.

156. See on the significance of co-operation in science Henry H. Bauer, Scientific Literacy and the Myth of the Scientific Method (1992) at pp.43-62 et passim. 


\section{Beyond Post-modernism: Interdisciplinarity and Intercultural Hermeneutics}

At all stages of comparative research (data acquisition, analysis and interpretation of the data, and actual in-depth comparison and eventual evaluation), the real problems are not moral or cultural blindness, ethnocentricity and legal imperialism, but the lack of full knowledge and understanding of foreign legal rules and cultures. Comparatists havepure and simple-an incomplete knowledge of many hard facts. ${ }^{157}$ They must know something about the historical, social, economic, political, cultural and psychological context which has made a rule or proposition what it is. Because thorough knowledge needs hard and extensive study, excellent language skills, good libraries, long experience, probably knowledge of life and legal practice within the foreign system, it is rarely acquired. In practice, the comparatist almost inevitably knows the legal order better in which she was trained. This asymmetry of knowledge alone may cause systematic mistakes. For instance, it may often be the case that-due to incomplete knowledge of details, of the context-the comparatist over-estimates the possibility of transfer.

Full understanding requires a comprehensive and interdisciplinary approach. Because "[a] legal order simultaneously encompasses systems of political arrangements, social relations, interpersonal interactional practices, economic processes, cultural categorisations, normative beliefs, psychological habits, philosophical perspectives, and ideological values", ${ }^{158}$ we must look not only at rules but at legal cultures, traditions, ideals, ideologies, identities, and entire legal discourses. This insight is far from new. Traditional functionalists have called for interdisciplinary

157. "Comparative law is superficial ... [lt] is hard enough to know in detail one branch of the law of one system, but to know the history of that branch and its relationship with that of some other system (and thus to possess a knowledge of the history of that as well) is well-nigh impossible." (Watson supra n.142 at p.10).

158. Ainsworth supra n.10 at p.28. 
research, albeit in different terms. ${ }^{159}$ With regard to the dangers of false (U.S.-centred, Eurocentric and hegemonic) universalism, interdisciplinarity and comprehensiveness appear, however, in a new light. They direct our attention to the moral and political, eventually technically dysfunctional, underpinning of rules in a historical, sociological and cultural perspective. So interdisciplinarity and comprehensiveness are a conditio sine qua non for avoiding erroneous assumptions on ostensibly "identical" societal problems and erroneous, de-contextualized evaluations of legal solutions.

The program just laid out does not inevitably manoeuvre itself into a "hermeneutic compulsion", as the critique formulates. ${ }^{160}$ This term is meant to explain that comprehensive, understanding comparison constitutes an infinite task because the standards of research and the pre-conditions for true understanding are so high and demanding that they can never be reached.

However, far from being under hermeneutic compulsion, comparative law after post-modernism can refer to the booming field of intercultural

159. Already Pierre Lepaulle, "The Function of Comparative Law", (1921-1922) 35 Harv.L.Rev. 838 at p.853: "First, it must be clear that a comparison restricted to one legal phenomenon in two countries is unscientific and misleading. A legal system is a unity, the whole of which expresses itself in each part; the same blood runs in the whole organism. An identical provision of the law of two countries may have wholly different moral backgrounds, may have been brought about by the interplay of wholly different forces and hence the similarity may be due to the purest coincidence-no more significant than the double meaning of a pun." Likewise, Rabel wrote in 1925, supra n.45 at p.5: "The material of reflection about legal problems must be the law of the entire globe, past and present, the relation of the law to the land, the climate, and race, with historical fates of peoples, - war, revolution, state-building, subjugation-, with religious and moral conceptions; ambitions and creative power of individuals; need of goods production and consumption; interests of ranks, parties, classes. Intellectual currents of all kinds are at work ... Everything is conditioned on everything else in social, economic and legal design." See also Rothacker, supra n.22 at p.31: "All comparison in a particular field of culture" must be done "with methodical attention to all other comparative sciences". "Hence no constitutional comparison, legal comparison etc. without information by analogous methods, problems, apories, results of comparative history of economies, religious history, history of languages, history of arts etc."

160. Berman, supra n.4 at pp.284-285. 
hermeneutics. ${ }^{161}$ Actually, classic hermeneutics ${ }^{162}$ is one of the intellectual roots of post-modernist theory, and modernised versions can usefully be brought back to the fore. Intercultural hermeneutics realises that the cultural Other is in principle not different from the intra-cultural or historical Other. As historical distance can be revealed and described through the interpretation of historical texts, cultural distance can be revealed, described, and conveyed. Intercultural hermeneutics thus presupposes, searches, finds and enlarges the overlaps between different cultures and philosophies. These overlaps make cross-cultural communication and understanding possible. ${ }^{163}$ As do languages, legal institutions differ from each other, but they are translatable-not perfectly, but at least approximately.

The quest for scientific rigor, careful study, attention to detail and to context is no compulsion, but a question of good scholarship. Only under the framework-premise is such study infinite because, only under that premise is the Other un-understandable, unrepresentable, incomparable. To scorn scrupulous scholarship as "chastened search for true understanding" and to disparage "all this ego suppression and careful listening"164 is a good excuse for not even trying.

161. See already in the eighties Holenstein supra n.76, most recently the focus section "Interkulturelle Kompetenz und Hermeneutik" in (1999) 47 Deutsche Zeitschrift fur Philosophie 407-477 with contributions by Hans Julius Schneider, Joachim Matthes, Axel Horstmann, Jurgen Straub/Shingo Shimada; Rosa supra n.72 at pp.10-42. See also Elmar Holenstein, "Intra- und interkulturelle Hermeneutik", in idem, Kullurphilosophische Perspektiven (1998) 257-287; Hcinz Kimmerle \& Franz M. Wimmer (Eds.), Philosophy and Democracy in Intercultural Perspective 1997; Notker Schneider, Ram A. Mall \& Dieter Lohmar (Eds.), Einheit und Vielfalt: Das Verstehen der Kulturen (1998).

162. Friedrich Schleiermacher, "Hermeneutik", in idem, Schrifien (Andreas Arndi Ed., 1996), pp.945-991 (orig. 1819); Wilhelm Dilthey, "Plan der Forsetzung zum Aufbau der geschichtlichen Welt in den Geisteswissenschaften", in iden, Gesammelie Schriften, Vol. VIl (4th ed. 1965), 189, at 216-220; Martin Heidegger, Sein und Zeir (15th ed. 1976), \$31-32 (pp.142-153) (orig. 1927); Hans Georg-Gadamer, "Hermeneutik I: Wahrheit und Methode", in idem, Gesammelie Werke, Vol. I (6th ed. 1990) (orig. 1960).

163. Axel Horstmann, "Interkulturelle Hermeneutik: Einc neue Theorie des Verstehens?." (1999) 47 Deutsche Zeitschrift far Philosophie 427 at p.438.

164. Kennedy supra n.1, al pp. 590 n.76 and 591 . 